\title{
Gambaran Pengelolaan (Hutan Kemasyarakatan) HKm di Indonesia
}

\author{
Muhdar $^{1 *}$, Gufron D.Dirawan ${ }^{2}$, Muhammad Wiharto $^{3}$ \\ ${ }^{1}$ Mahasiswa Program Doktor Pendidikan Kependudukan dan Lingkungan Hidup \\ Pascasarjana Universitas Negeri Makassar \\ *Email: muhdarku@gmail.com \\ ${ }^{2}$ Program Studi Pendidikan Kependudukan dan Lingkungan Hidup \\ Pascasarjana Universitas Negeri Makassar \\ ${ }^{3}$ Program Studi Pendidikan Teknologi Pertanian, Fakultas Teknik \\ Universitas Negeri Makassar
}

(c) 2018 - UEJ Program Studi Pendidikan Kependudukan dan Lingkungan Hidup Universitas Negeri Makassar.

Ini adalah artikel dengan akses terbuka dibawah Licensi CC BY-NC-4.0

(http:/creativecommons.org/licenses/by-nc/4.0)

\begin{abstract}
This study aims: To describe the management of Community Forestry (HKm) in Indonesia. Through a theoretical study of some of the results of research on community forest management in Indonesia. Then the results of this study show that the management of HKm is more oriented to short-term economic interests, not ecologically and economically sustainable, resulting in damage to forest functions, both ecological and economic functions, due to various problems faced by the field and inequality between government regulations. The solution to the results of this study is that in the management of Community Forestry, it is necessary to pay attention to three principles, namely: a) Benefit and are ecologically, economically, socially and culturally sustainable, b). deliberation; and justice for the whole community.
\end{abstract}

Keywords: Management, Community Forestry, Ecological insight, Sustainable economy

\section{PENDAHULUAN}

Program Hutan Kemasyarakatan $(\mathrm{HKm})$ merupakan program pemerintah yang tidak sekedar memberikan alternative agar masyarakat sekitar hutan dapat mengelola hutan akan tetapi juga memberikan kesempatan dan kepercayaan kepada masyarakat untuk bersama-sama dengan berbagai pihak mengelola sumber daya hutan secara penuh agar nantinya dapat tercapai kesejahteraan rakyat dengan senantiasa memperhatikan upaya pelestarian alamnya (Erdi, 2011).

Keberhasilan kegiatan Hutan Kemasyarakatan sangat ditentukan oleh ketepatan perencanaan, kesiapan kelembagaan masyarakat, serta dukungan Pemerintah Daerah. Oleh karena itu proses perencanaan harus dilakukan secara cermat dengan melibatkan instansi terkait. Pedoman ini merupakan bagian dari proses penyusunan perencanaan yang harus dilaksanakan secara terkoordinasi dengan para pihak di lapangan. Pedoman ini merupakan petunjuk teknis yang bersifat arahan, sehingga cakupannya dapat dikembangkan sesuai dengan karakteristik masing - masing wilayah. Acuan utama adalah peraturan tentang penyelenggaraan Hutan Kemasyarakatan. Melalui pedoman ini diharapkan kegiatan pengembangan Hutan Kemasyarakatan dapat terselenggara dengan baik untuk mewujudkan peningkatan kesejahteraan masyarakat melalui pengelolaan hutan lestari bersama masyarakat (Ritonga W.M dan Rochana E. 2013).

Secara nasional, pelaksanaan konsep HKm telah dikembangkan pada 22 propinsi dengan luas keseluruhan sekitar 448.217 Ha yang terdiri dari areal usulan penetapan wilayah HKm (162. 112,91 $\mathrm{Ha})$, areal pembangunan $\mathrm{HKm}(208.327 \mathrm{Ha})$, areal kerja $(55.420 \mathrm{Ha})$ dan areal yang diberi ijin sementara $(62.357 \mathrm{Ha})$. Total kelompok masyarakat yang terlibat pada kegiatan HKm adalah 519 kelompok (Nandini, 2013). 
UNM Environmental Journals, Vol. 2 No. 1 Desember 2018 hal. $18-23$

\section{METODE}

Penelitian ini menggunakan pendekatan kajian teori berdasakan penelitian - penelitian tentang pengelolaan Hutan Kemasyarakatan di Indonesia.

\section{HASIL DAN PEMBAHASAN}

\section{Hasil}

Berdasarkan hasil kajian penelitian dari beberapa peneliti, pada tabel 1 diidentifikasi beberapa hasil penelitia dalam pengelolaan $\mathrm{HKm}$ di Indonesia.

Tabel 1 Daftar Identifikasi beberapa hasil penelitian dari berbagai wilayah Indonesia

\begin{tabular}{|c|c|c|}
\hline Peneliti & Judul & Hasil Penelitiaan \\
\hline $\begin{array}{l}\text { Ryke Nandini } \\
\text { (2013) }\end{array}$ & $\begin{array}{l}\text { Evaluasi Pengelolaan } \\
\text { Hutan } \\
\text { Kemasyarakatan } \\
\text { (Hkm) pada Hutan } \\
\text { Produksi dan Hutan } \\
\text { Lindung di Pulau } \\
\text { Lombok }\end{array}$ & $\begin{array}{l}\text { Faktor pembatas dari aspek teknik yang } \\
\text { menyebabkan kondisi HKm di hutan } \\
\text { lindung berada dalam kondisi sedang } \\
\text { adalah usaha tani dan konservasi, faktor } \\
\text { pembatas kelembagaan adalah sistem } \\
\text { pengelolaan kelembagaan, sedangkan } \\
\text { faktor pembatas ekonomi adalah dampak } \\
\text { ekonomi HKm. }\end{array}$ \\
\hline $\begin{array}{l}\text { Tasmin } \\
\text { Tangngareng } \\
\text { dan } \\
\text { Muhammad } \\
\text { Ridha (2016) }\end{array}$ & $\begin{array}{l}\text { Pelaksanaan } \\
\text { Pengelolaan Hutan } \\
\text { Kemasyarakatan } \\
\text { (HKM) di Desa } \\
\text { Bukit Indah } \\
\text { Bulukumba: Batasan } \\
\text { Dan Kemungkinan }\end{array}$ & $\begin{array}{l}\text { Skema Community Base Forest } \\
\text { Manegement (CBFM) tidak banyak berarti } \\
\text { bagi upaya pembangunan masyarakat, } \\
\text { pengentasan kemiskinan di desa-desa } \\
\text { dalam dan sekitar hutan serta membangun } \\
\text { struktur penguasaan sumberdaya yang } \\
\text { lebih adil di desa. }\end{array}$ \\
\hline $\begin{array}{l}\text { Yanyan } \\
\text { Ruchyansya, } \\
\text { Christine } \\
\text { Wulandari, } \\
\text { dan Melya } \\
\text { Riniarti } \\
(2018)\end{array}$ & $\begin{array}{l}\text { Pengaruh Pola } \\
\text { Budidaya Pada } \\
\text { Hutan } \\
\text { Kemasyarakatan di } \\
\text { Areal Kelola KPH } \\
\text { VIII Batutegi } \\
\text { Terhadap Pendapat } \\
\text { Petani dan } \\
\text { Kesuburan Tanah }\end{array}$ & $\begin{array}{l}\text { Program Perhutanan Sosial (HKm) } \\
\text { ternyata tidak menimbulkan perbedaan } \\
\text { perilaku antara petani yang telah dan yang } \\
\text { belum memiliki izin pengelolaan, karena } \\
\text { masih ditemukan petani yang } \\
\text { melaksanakan budidaya monokultur } \\
\text { walaupun telah memiliki IUPHKm. Pada } \\
\text { tahun-tahun awal pola agroforestri tidak } \\
\text { dapat menjamin tercapainya pemenuhan } \\
\text { kebutuhan dasar masyarakat dari hasil } \\
\text { agroforestri maupun peningkatan } \\
\text { kesuburan tanah. }\end{array}$ \\
\hline $\begin{array}{l}\text { Reni Yulian, } \\
\text { Rudi } \\
\text { Hilmanto, dan } \\
\text { Susni } \\
\text { Herwanti } \\
\text { (2016) }\end{array}$ & $\begin{array}{l}\text { Nilai Tukar } \\
\text { Pendapatan Rumah } \\
\text { Tangga Petani } \\
\text { Agroforestri di Hutan } \\
\text { Kemasyarakatan } \\
\text { Bina Wana Jaya I } \\
\text { Kesatuan Pengolaan } \\
\text { Hutan Lindung } \\
\text { Batutegi Kabupaten } \\
\text { Tanggamus }\end{array}$ & $\begin{array}{l}\text { Faktor-faktor pembentuk NTPRP terdiri } \\
\text { dari pendapatan yang berasal dari } \\
\text { pertanian dan non-pertanian (usaha } \\
\text { agroforestri, usaha non-agroforestri, buruh } \\
\text { tani dan buruh nonpertanian) dan } \\
\text { pengeluaran yang terdiri dari biaya } \\
\text { produksi usaha agroforestri maupun usaha } \\
\text { non-agroforestri serta biaya konsumsi. }\end{array}$ \\
\hline $\begin{array}{l}\text { Sanudin, San } \\
\text { Afri Awang, }\end{array}$ & $\begin{array}{l}\text { Perkembangan Hutan } \\
\text { Kemasyarakatan Di }\end{array}$ & $\begin{array}{l}\text { Permasalahan utama dalam implementasi } \\
\text { HKm adalah dukungan anggaran dari }\end{array}$ \\
\hline
\end{tabular}




\begin{tabular}{|c|c|c|}
\hline $\begin{array}{l}\text { Ronggo } \\
\text { Sadono dan } \\
\text { Ris Hadi } \\
\text { Purwanto } \\
\text { (2016) }\end{array}$ & Provinsi Lampung & $\begin{array}{l}\text { pemerintah daerah kurang memadai akibat } \\
\text { HKm belum menjadi program prioritas } \\
\text { sehingga pembinaan dan pendampingan } \\
\text { yang dilakukan kurang maksimal. } \\
\text { Pengembangan kelembagaan kelompok } \\
\text { tani, lahan, dan kewirausahaan merupakan } \\
\text { tiga kunci penting dalam mencapai tujuan } \\
\text { HKm yakni untuk meningkatkan } \\
\text { kesejahteraan masyarakat dan menjaga } \\
\text { kelestarian hutan }\end{array}$ \\
\hline $\begin{array}{l}\text { Dian } \\
\text { Kagungan } \\
\text { (2012) }\end{array}$ & $\begin{array}{l}\text { Kebijakan Hutan } \\
\text { Kemasyarakatan } \\
\text { (HKM) Di } \\
\text { Kabupaten } \\
\text { Tanggamus Provinsi } \\
\text { Lampung }\end{array}$ & $\begin{array}{l}\text { Persoalan- persoalan lain yang tersisa } \\
\text { adalah keterbatasan jumlah dan kualitas } \\
\text { tenaga penyuluhan yang merupakan } \\
\text { fenomena umum di negara-negara } \\
\text { berkembang. Untuk amat penting untuk } \\
\text { mengakomodasi keterbatasan itu serta } \\
\text { untuk menciptakan alat bantu penyuluhan } \\
\text { yang handal dengan penjelasan dan } \\
\text { durabilitas yang panjang dan terperinci } \\
\text { (seperti media panduan Hutan } \\
\text { Kemasyarakatan). }\end{array}$ \\
\hline $\begin{array}{l}\text { Deasy Fitria, } \\
\text { Arya Hadi } \\
\text { Dharmawan, } \\
\text { dan Lilik Budi } \\
\text { Prasetyo } \\
\text { (2017) }\end{array}$ & $\begin{array}{l}\text { Peran Hutan } \\
\text { Kemasyarakatan } \\
\text { Melalui Inisiatif } \\
\text { Karbon Terhadap } \\
\text { Nafkah Rumah } \\
\text { Tangga Petani Di } \\
\text { Kabupaten Gunung } \\
\text { Kidul Daerah } \\
\text { Istimewa Yogyakarta }\end{array}$ & $\begin{array}{l}\text { Perdagangan karbon akan menguntungkan } \\
\text { dalam upaya menjaga lingkungan, karena } \\
\text { tiap tahunnya cadangan karbon yang } \\
\text { tersimpan di areal } \mathrm{HKm} \text { akan semakin } \\
\text { meningkat dikarenakan tidak dilakukan } \\
\text { penebangan. }\end{array}$ \\
\hline $\begin{array}{l}\text { Dewi ayu } \\
\text { Hidayati dan } \\
\text { Damar } \\
\text { Wibisono } \\
(2016)\end{array}$ & $\begin{array}{l}\text { Pola Iinteraksi } \\
\text { Pemerintah dan } \\
\text { Masyarakat dalam } \\
\text { Kebijakan } \\
\text { Pemanfataan Hutan } \\
\text { Kemasyarakatan Di } \\
\text { Kawasan Register } 25 \\
\text { dan 26 Kecamatan } \\
\text { Kelumbayan } \\
\text { Kabupaten } \\
\text { Tanggamus }\end{array}$ & $\begin{array}{l}\text { Dalam interaksi yang terjadi pada } \\
\text { masyarakat pengelola hutan kemasyarakat } \\
\text { di Kabupaten Tanggamus, faktor sugesti } \\
\text { sebagian masyarakat yang belum } \\
\text { memahami tujuan program Hkm dan tidak } \\
\text { berminat mengikuti program ini, bukan } \\
\text { tidak mungkin akan mempengaruhi } \\
\text { anggota masyarakat lainnya yang juga } \\
\text { melum memahami tentang program Hkm } \\
\text { ini; }\end{array}$ \\
\hline $\begin{array}{l}\text { Shinta Ayu } \\
\text { Ariescha } \\
\text { (2016) }\end{array}$ & $\begin{array}{l}\text { Struktur dan } \\
\text { Komposisi Spesies } \\
\text { Komunitas Pohon } \\
\text { dan Beberapa } \\
\text { Ketinggian Tempat } \\
\text { di Hutan } \\
\text { Kemasyarakatan } \\
\text { Watoe Gembel, } \\
\text { Kulon Progo, Daerah } \\
\text { Istimewa Yogyakarta }\end{array}$ & $\begin{array}{l}\text { Manfaat potensi pohon yang ditemukan di } \\
\text { Hutan Kemasyarakatan Watoe Gembel } \\
\text { sebagai penyedia bahan baku industri dan } \\
\text { konstruksi, bahan baku furnitur, sumber } \\
\text { obat tradisional, bahan baku kosmetik, } \\
\text { bahan baku minyak, kerajinan, tanaman } \\
\text { peneduh, dan insektisida. }\end{array}$ \\
\hline
\end{tabular}

Tabel diatas menunjukkan bahwa Pengelolaan HKm lebih berorientasi kepada kepentingan 
UNM Environmental Journals, Vol. 2 No. 1 Desember 2018 hal. $18-23$

ekonomi jangka pendek, belum berwawasan ekologis dan ekonomi berkelanjutan mengakibatkan terjadinya kerusakan fungsi hutan, baik fungsi ekologi maupun ekonomi.

\section{Pembahasan}

\section{Penelitian Ryke Nandini (2013)}

Adapun hasil penelitian Ryke sebagai berikut;

Hasil evaluasi HKm di hutan produksi yang diwakili oleh HKm Unit Sambelia menunjukkan bahwa HKm di hutan produksi berada pada kondisi sedang dengan skor 47,36. Faktor pembatas dari aspek teknik yang menyebabkan kondisi HKm di hutan produksi berada dalam kondisi sedang adalah kondisi biofisik dan kondisi tanaman, faktor pembatas kelembagaan adalah sistem pengelolaan kelembagaan, sedangkan faktor pembatas ekonomi adalah potensi ekonomi Hkm.

Hasil evaluasi $\mathrm{HKm}$ di hutan lindung yang diwakili oleh $\mathrm{HKm}$ Sesaot dan $\mathrm{HKm}$ Darussadiqien menunjukkan bahwa HKm di hutan lindung berada pada kondisi sedang dengan skor masing-masing 53,17 (HKm Sesaot) dan 45,77 (HKm Darussadiqien). Faktor pembatas dari aspek teknik yang menyebabkan kondisi HKm di hutan lindung berada dalam kondisi sedang adalah usaha tani dan konservasi, faktor pembatas kelembagaan adalah sistem pengelolaan kelembagaan, sedangkan faktor pembatas ekonomi adalah dampak ekonomi HKm.

\section{Penelitian Tasmin \& Ridha (2016)}

Pada Penelitian ini menguraikan penggunaan Skema Community Base Forest Management (CBFM) sebagai sebuah alternatif bisa jadi amat berguna bagi masyarakat, terutama kelompok tani Hutan yang mendapatkan izin kelola berupa IUPHKm. Pelajaran dari desa Bukit Indah ini, bisa menjelaskan bagaimana skema ini telah cukup berhasil mendorong produktifitas dan legalisasi lahan kelola petani. Meskipun, ketika kita liat secara lebih mendalam, terutama pada soal luas hak kelola yang timpang, skema ini menjadi tidak banyak berarti bagi upaya pembangunan masyarakat, pengentasan kemiskinan di desa-desa dalam dan sekitar hutan serta membangun struktur penguasaan sumberdaya yang lebih adil di desa. Pelajaran dari dua kelompok tani hutan (KTH) di Desa Bukit Indah kecamatan Gantarang Kabupaten Bulukumba bisa memberikan rekomendasi dan masukan bagi kebijakan kehutanan lanjutan yang tidak bisa tidak, harus membuka mata atas ketidakadilan struktur penguasaan lahan di dalam hutan. Bukan hanya antara petani dan korporasi saja tetapi juga antara sesama petani.

\section{Penelitian Yanyan dkk (2018)}

Dalam Penelitian ini Program Perhutanan Sosial (HKm) ternyata tidak menimbulkan perbedaan perilaku antara petani yang telah dan yang belum memiliki izin pengelolaan, karena masih ditemukan petani yang melaksanakan budidaya monokultur walaupun telah memiliki IUPHKm. Pada tahun-tahun awal pola agroforestri tidak dapat menjamin tercapainya pemenuhan kebutuhan dasar masyarakat dari hasil agroforestri maupun peningkatan kesuburan tanah.

\section{Penelitian Rizki dkk (2017)}

Adapun hasil penelitian ini menguraikan: Karakteristik sosial dan ekonomi masyarakat di Desa Sindang Pagar yang mengelola HKm tergolong kedalam usia yang produktif untuk bekerja meskipun memiliki tingkat pendidikan yang rendah, sebagian besar responden memilki jumlah tanggungan keluarga yang cukup banyak meskipun demikian responden mengelola lahan yang cukup luas dan memilki pekerjaan sampingan sehingga pendapatan responden terbilang cukup tinggi.

Secara keseluruhan pengelolaan HKm di Desa Sindang Pagar termasuk kedalam kategori baik. Kegiatan pengelolaan terdiri dari aspek perencanaan termasuk kedalam kategori sedang, aspek organisasi termasuk kedalam kategori sedang, aspek pelaksanaan termasuk kedalam kategori baik dan aspek monitoring evaluasi termasuk kedalam kategori sedang.

\section{Penelitian Reni, dkk (2016)}

Dalam Penelitian ini menguraikan Nilai Tukar Pendapatan Rumah Tangga Petani Agroforestri di HKm Bina Wana Jaya I KPHL Batutegi pada kelompok pengelolaan lahan sempit sebesar 0,61 dan dikategorikan belum sejahtera; sedangkan kelompok pengelolaan lahan sedang dan luas dengan 
NTPRP sebesar 1,04 dan 1,62 dikategorikan sejahtera.

Faktor-faktor pembentuk NTPRP terdiri dari pendapatan yang berasal dari pertanian dan nonpertanian (usaha agroforestri, usaha non-agroforestri, buruh tani dan buruh nonpertanian) dan pengeluaran yang terdiri dari biaya produksi usaha agroforestri maupun usaha non-agroforestri serta biaya konsumsi.

6. Peneltian Sanudin, dkk (2016)

Adapun penejelasan dalam penelitian ini menguraikan bahwa Hutan Kemasyarakatan $(\mathrm{HKm})$ di Provinsi Lampung merupakan solusi terhadap permasalahan konflik pengelolaan hutan dengan tingkat ketergantungan masyarakat terhadap hutan yang tinggi telah mendorong kegiatan penggarapan lahan di kawasan hutan. HKm di Provinsi Lampung tersebar di 9 kabupaten dari 15 kabupaten/kota yang ada baik yang sudah mendapatkan IUPHKm, mendapatkan PAK, maupun sedang mengusulkan PAK. Permasalahan utama dalam implementasi HKm adalah dukungan anggaran dari pemerintah daerah kurang memadai akibat $\mathrm{HKm}$ belum menjadi program prioritas sehingga pembinaan dan pendampingan yang dilakukan kurang maksimal. Pengembangan kelembagaan kelompok tani, lahan, dan kewirausahaan merupakan tiga kunci penting dalam mencapai tujuan HKm yakni untuk meningkatkan kesejahteraan masyarakat dan menjaga kelestarian hutan.

\section{Dian Kagungan (2012)}

Dalam penelitian ini menguraikan Persoalan- persoalan lain yang tersisa adalah keterbatasan jumlah dan kualitas tenaga penyuluhan yang merupakan fenomena umum di negara-negara berkembang. Untuk amat penting untuk mengakomodasi keterbatasan itu serta untuk menciptakan alat bantu penyuluhan yang handal dengan penjelasan dan durabilitas yang panjang dan terperinci (seperti media panduan Hutan Kemasyarakatan). Untuk itu perlu segera dikembangkan dan dimasyara-katkan alat bantu partisipatif sebagai alternatif percepatan proses pengajuan perizinan Hutan kemasyarakatan (Hkm) di Kabupaten Tanggamus, terutama di tingkat kelompok tani berdasarkan kebutuhan masyarakat setempat dan tersedianya publikasi peraturan yang berkaitan dengan penyelenggaraan hutan kemasyarakatan (HKm) di tingkat pekon.

Di samping itu perlu dilakukan revitalisasi program penyuluhan antara lain melalui penyediaan buku panduan Hutan kemasyarakatan bagi calon kelompok maupun kelompok-kelompok tani Hutan kemasyarakatan yang akan mengajukan izin kelola Hkm serta upaya-upaya penguatan kelembagaan kepada semua stakeholder yang berkompeten terhadap perkembangan Hutan kemasyarakatan $(\mathrm{Hkm})$ utamanya di Provinsi Lampung dengan tetap memperhatikan prinsip kelestarian hutan demi kehidupan bersama.

\section{KESIMPULAN DAN SARAN}

Adapun kesimpulan dari artikel ini bahwa terdapat kecenderungan masyarakat dalam memanfaatkan kawasan hutan yang menjadi wilayah $\mathrm{Hkm}$ masih jauh dari konsep pengelolaan hutan yang berkelanjutan. Hal tersebut bisa dilihat dari perilaku masyarakat dalam pengelolaan hutan dalam kawasan HKm sama dengan aktifitas berladang. Terjadi penggundulan hutan yang beresiko terhadap terjadinya deforestrasi hutan. Hal tersebut tentu bertentangan dengan salah satu tujuan HKm itu sendiri yaitu pemanfaatan hutan yang lestari atau berkelanjutan.

Berdasarkan hal - hal yang telah diurakan tersebut, maka perlu sebuah kebijakan dalam HKm berupa sebuah model pengelolahan yang mendukung tercapainya pengelolaan hutan untuk kepentingan ekonomi masyarakat di kawasan hutan dengan tetap menjaga keberlanjutan dan kelestarian hutan sesuai dengan tujuan program $\mathrm{HKm}$ itu sendiri sangat penting 
UNM Environmental Journals, Vol. 2 No. 1 Desember 2018 hal. $18-23$

\section{Referensi}

C Abdillah, D., 2015. Pengembangan Daya Tarik Wisata Planetarium Jagad Raya Tenggarong. JDP 2, 63-80.

Amirudin, A., Handoyo, B., Soekamto, H., 2015. Characteristics of Desaster Pre Liminary Research in Developing Learning Model of Environment Education Based on The Disaster in Efford to Grow an Cultural Anticipatory. J. Pendidik. Geogr. 20, 59-67. https://doi.org/10.17977/um017v20i12015p059

Azwir, A., Jalaluddin, J., Ibrahim, I., 2017. Peranan Masyarakat Dalam Menjaga Kelestarian Hutan Sebagai Sumber Kehidupan. J. Ekon. Manaj. Dan Akunt. JEMSI 3.

BPS NTB. 2016. Jumlah penduduk Kabupaten Dompu tahun 2015.

Chambers, R 1997. Whose Reality Counts, Putting the First Last ,IIED London UK.

DPD RI, 2013. Rancangan Undang-Undang Tentang Perubahan Atas Undang-Undang Nomor 10 Tahun 2009 Tentang Kepariwisataan, Dewan Perwakilan Daerah Republik Indonesia.

Fitria, D., Dharmawan, A., H., Prasetyo, L., B,. 2017. Peran Hutan Kemasyarakatan Melalui Inisiatif Karbon Terhadap Nafkah Rumah Tangga Petani Di Kabupaten Gunung Kidul Daerah Istimewa Yogyakarta. Jurnal Silvikultur Tropika. Vol 8 No 1 (35-40)

Festus, I.A., 2014. Key Issues On Landscape Planning In The Context Of Environmental Sustainability. Eur. Sci. J. ESJ 10.

Frantz, C.M., Mayer, F.S., 2014. The importance of connection to nature in assessing environmental education programs. Stud. Educ. Eval. Complete, 85-89. https://doi.org/10.1016/j.stueduc.2013.10.001

Hadzi, Abdulloh. 2016. Pembelajaran agama dan lingkungan dalam kultur sekolah alam (Membumikan Kesadaran Lingkungan Sejak Dini). Tadrîs, Vol. 11, No. 1, 20 - 48

Hidayanti, D., A., Wibisono, D,. 2016. Pola Iinteraksi Pemerintah dan Masyarakat dalam Kebijakan PemanfataanHutan Kemasyarakatan Di Kawasan Register 25 dan 26 Kecamatan Kelumbayan Kabupaten Tanggamus. Universitas Lampung

Hidayat, Ara. 2015. Pendidikan Islam dan Lingkungan Hidup. Jurnal Pendidikan Islam, Vol. 4, No. 2, 373 - 389.

Ilma, S,.\& Wijarin, F,. 2018. Efektivitas buku ajar pendidikan Lingkungan hidup berbasis potensi lokal Tarakan. Pedagogi Hayati, Vol. 2, No. 1.

Kumalasari, d., 2014. Implementasi kebijakan pengelolaan air limbah domestik di $\quad$ kota $\quad$ yogyakarta $(\mathrm{PhD}$ Thesis). Fakultas Ilmu Sosial.

Lestari, U., 2016. Hutan Kemasyarakatan, Kemiskinan Dan Perubahan Iklim 4.

Maryadi, 2016. Nilai-Nilai Pendidikan Lingkungan Dalam Al-Qur'an Surah Al-A'raf Ayat 56 (Telaah Atas Tafsir Al-Misbah. Universitas Islam Negeri Raden Fatah, Palembang.

Metro, V., 2013. Geodesi untuk negeri: analisis alokasi hutan sebagai daerah pengembangan energi terbarukan geothermal di kawasan hutan lindung batutegi dengan menggunakan sistem informasi geografis. GEOD. UNTUK NEGERI.

Nandini, R., 2013. Evaluasi Pengelolaan Hutan Kemasyarakatan (Hkm) Pada Hutan Produksi Dan Hutan Lindung Di Pulau Lombok. J. Penelit. Hutan Tanam. 10, 43-55. https://doi.org/10.20886/ jpht.2013.10.1.43$\underline{55}$. 